\title{
PKC Is a Target to Modulate the Expression of Receptor Mediated Endocytosis (RME) Mice Macrophages BALB/c for Optimizing the Phagocytosis toward Candida albicans
}

\author{
Adi Prayitno ${ }^{1 *}$, Elyana Asnar ${ }^{2}$, Okid Parama Astirin ${ }^{3}$, Anief Nur Artanti ${ }^{4}$, Meutia Srikandi Fitria ${ }^{3}$, \\ Eva Agustina Perwitasari ${ }^{3}$, Suhartono Taat Putra ${ }^{2}$ \\ ${ }^{1}$ Department of Dental and Oral Disease, Faculty of Medicine, University of Sebelas Maret, Surakarta, Indonesia \\ ${ }^{2}$ Departement of Pathobiology, Faculty of Medicine, University of Airlangga, Surabaya, Indonesia \\ ${ }^{3}$ Department of Biology, Faculty of Mathematics and Natural Science, University of Sebelas Maret, Surakarta, Indonesia \\ ${ }^{4}$ Department of Pharmacy, Faculty of Mathematics and Natural Science, University of Sebelas Maret, Surakarta, Indonesia \\ Email: *drgadiprayitno@yahoo.com
}

Received August 2, 2013; revised September 3, 2013; accepted September 11, 2013

Copyright (C) 2013 Adi Prayitno et al. This is an open access article distributed under the Creative Commons Attribution License, which permits unrestricted use, distribution, and reproduction in any medium, provided the original work is properly cited.

\begin{abstract}
Introduction: The existence of receptor-mediated endocytosis (RME) means that selectivity and selectivity occurs in capturing macromolecules. Protein kinase C (PKC) which can be expressed by almost all cells are proteins important in signal transduction groove that plays a role in a number of cell activity, e.g. phagocytosis. Aims: The purpose of this study is to determine the expression of RME after modulating the PKC which is characterized by the number of Candida albicans cells attached to the surface of macrophages. Methods: Peritoneal macrophages cultured BALB/c mice are treated with PMA and/or bisindolylmaleimides of providing levels of $5 \mathrm{ng} / \mathrm{ml}$ to $100 \mathrm{ng} / \mathrm{ml}$ for 10 minutes. Then immediately insert Candida albicans and observe every 30 minutes for 120 minutes. The research design used the same subject. Data collected in the form of number of Candida albicans cells attached to the surface of macrophages are analyzed with ANOVA statistical test (one way) to show the differences between treatments. Results: The test shows statistically significant difference in the number of Candida albicans cells attached to the surface of macrophages after administration of various levels of PMA $(p<0.001)$. The higher level of PMA is given, the more active the PKC is, the more RME are formed, the more Candida albicans cells attached to the surface of macrophages. Another result shows statistically significant difference in the number of Candida albicans cells attached to the surface of macrophages after administration of various levels of bisindolylmaleimides $(p<0.001)$. The higher level of bisindolylmaleimide is given, the less active PKC is, and the less RME are formed, the less Candida albicans cells attached to the surface of macrophages. Conclusion: Research shows that activator PKC (PMA) can increase the expression of RME on macrophages. Another research shows that inhibitor PKC (bisindolylmaleimides) can decrease the expression of RME on macrophages.
\end{abstract}

Keywords: PMA; Bisindolylmaleimides; RME; PKC; Phagocytosis

\section{Introduction}

Phorbol esters are polycyclic alcohol that is derived from croton oil. Phorbol ester is highly carcinogenic and known as tumor promoters [1-3]. How phorbol ester activates PKC is identical to how diacylglycerol (DAG) activates PKC. Phorbol ester activation is persistent, because it is very similar to the DAG and not immediately degraded $[2,3]$. Bisindolylmaleimides is a potent and selective in-

\footnotetext{
*Corresponding author.
}

hibitor of Protein kinase $\mathrm{C}$ which provides evidence for the potential use of PKC inhibitor as therapeutic immunomodulators [4]. Protein kinase C (PKC) family is a heterogeneous family of phospholipid-dependent kinases [5]. Protein kinase $C$ has a number of important roles in cellular growth and differentiation, cellular metabolism, and transcriptional activation, most of which are not well understood [2,3,6-8]. Protein kinase C as allosteric enzyme can be modulated so it can make a pharmacological target $[4,9,10]$. 
Candida albicans is the most common organism to be associated with superficial candidosis. Oral colonization may originate early in infancy, although its incidence is increased by a number of factors, including hospitalization and bottle feeding. Some factors are systemic, and others are related to local conditions [11]. Little is known about the precise mechanisms involved in immunity to fungal infection. Macrophages and $\mathrm{T}$ cells immunity may be implicated in resistance to fungal infection [5,12-14].

The role of PKC, expression of receptor mediated endocytosis and phagocytosis toward Candida albicans may be explained by pathobiology examination $[15,16]$. This concept gives a chance to explain how to modulate immune response toward Candida albicans.

The existence of receptor-mediated endocytosis (RME) means for selectivity and effectiveness of arresting macromolecules that may be in very low concentrations in the extracellular fluid, e.g. controlled by a cell receptor to capture various types of substrates, including hormones, growth factors, enzymes-enzymes, and plasma proteins $[2,17,18]$. Then that macromolecules outside the cell have been collected and attached to the cell surface or plasma membrane into the cell to form a basin which means that RME has become the receptor binding in the area at the plasma membrane, known as coated pits [2,19]. Some receptors are concentrated in coated pits for a long time with a fixed concentration in the plasma membrane [2, 20-22].

\section{Method}

Macrophages obtained from the peritoneal cavity of mice $\mathrm{BALB} / \mathrm{c}$ done in a way as is done by Colligan, et al. with some modifications [23]. Macrophages obtained by using a $10 \mathrm{ml}$ syringe and hypodermic needle $25 \mathrm{G}$. The results collected in sizes $25 \mathrm{ml}$ centrifuge tube and stored on ice. Macrophage cultures performed in culture dishes with a diameter of $20 \mathrm{~mm}$. Macrophages were distributed into each well of the plate so that the culture wells containing an average of 1000 cells. For ease of painting it on the basis of prior pitting the cover glass is placed before the cell is inserted. Further culture medium Roswell Park Memorial Institute (RPMI) 1640 (Sigma Chem. Co.. St. Louis, USA) inserted into the wells as much as $10 \mathrm{ml}$. Medium replacement done once every 24 hours and incubated at room temperature.

Before treated culture medium were taken and cultured cells were washed with PBS-10F (PD: $137 \mathrm{nM}-\mathrm{NaCl}-$ $\mathrm{KCl} 3 \mathrm{nM}, 7$ nM-Phosphate Buffer, $\mathrm{pH}$ 7.4) and subsequently given the PMA (Sigma Chem. Co.., St. Louis, USA) for 10 minutes in the levels of $5 \mathrm{ng} / \mathrm{ml}$ to 100 $\mathrm{ng} / \mathrm{ml}$ at room temperature. After the AMF in the exhaust and cleaned with PBS-10F, added $C$. albicans approximately 200 cells per well and were observed every 30 min for 120 minutes [24,25].
After the observation period finish the glass cover at the base of the existing wells cell culture was taken and carried the painting with Giemsa (MERCK). Nikkon microscope equipped with a photo tool used to document the results with 100 multiple magnification, every $30 \mathrm{mi}-$ nutes for 120 minutes [2].

\section{Result}

The number of Candida albicans cells attached to the surface of macrophages can be seen in Figure 1 below, The test shows statistically significant difference in the number of Candida albicans cells attached to the surface of macrophages after administration of various levels of PMA ( $p<0.001)$. The higher level of PMA is given, the more active PKC, the more RME are formed, the more Candida albicans cells attached to the surface of macrophages (Table 1).

Another result showed statistically significant difference in the number of Candida albicans cells attached to the surface of macrophages after administration of various levels of bisindolylmaleimides $(p<0.001)$. The higher level of bisindolylmaleimide is given, the less active PKC, the less RME are formed, less Candida albicans cells attached to the surface of macrophages (Table 2).

\section{Discussion}

Phorbol Ester said can activate PKC. Polyciclic alcohol that derivate from croton oil is very carcinogenic, so it known as tumor promoter. Phorbol ester activate PKC because they similarity with diacylglycerol. The activity is persistent, because phorbol ester is similar with diacylglycerol which can't quickly degradated. If PKCs are going active can increases the signal transduction activity for cells activity. Phorbol ester also can increase the macropinicytosis toward Lucifer Yellow [3,26,27]. Diacylglycerol had two important signal pathways. First, they are break further for release the arachidonic acid, its

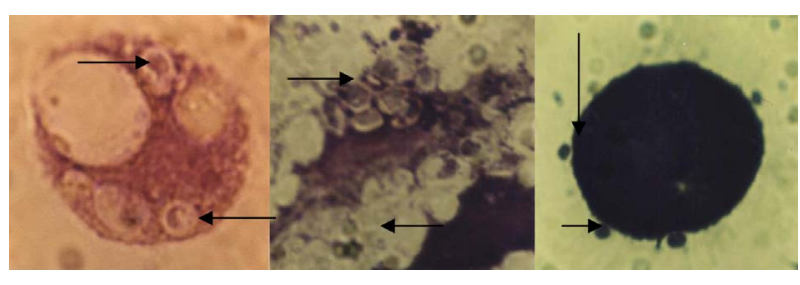

(a)

(b)

(c)

Figure 1. (a): Culture of phagocytozed macrophage toward Candida albicans before treated; (b): Culture of phagocytozed macrophage toward Candida albicans after treatment. We can look the the number of Candida albicans traped into complete phagosomes after treated with $100 \mathrm{ng} / \mathrm{ml}$ PMA; (c): Culture of phagocytozed macrophage toward Candida albicans after treatment. We can looks the the number of Candida albicans traped into complete phagosomes after treated with $100 \mathrm{ng} / \mathrm{ml}$ GF 109203x, and. 
Table 1. Phagocytic index of macrophage phagocytozised activity toward $C$. albicans after administration with many concentrations of PMA in 30 minutes and 120 minutes. The higher level of PMA is given, the more PKCs are active, the more RMEs are formed, the more Candida albicans cells attached to the surface of macrophages ( $\%$ at least one fungi attached, collom 2).

\begin{tabular}{|c|c|c|c|c|c|}
\hline \multirow{3}{*}{$\begin{array}{l}\text { Concentration } \\
\text { of PMA }\end{array}$} & \multirow{3}{*}{$\%$} & \multicolumn{4}{|c|}{ phagocytic } \\
\hline & & \multicolumn{2}{|c|}{ per positive cell ${ }^{\#}$} & \multicolumn{2}{|c|}{ index } \\
\hline & & $30^{\prime}$ & $120^{\prime}$ & $30^{\prime}$ & $120^{\prime}$ \\
\hline $0 \mathrm{ng} / \mathrm{ml}$ & 95 & 2 & 10 & 19.0 & 92.0 \\
\hline $5 \mathrm{ng} / \mathrm{ml}$ & 95 & 2 & 6 & 19.0 & 57.0 \\
\hline $25 \mathrm{ng} / \mathrm{ml}$ & 90 & 4 & 6 & 36.0 & 54.0 \\
\hline $50 \mathrm{ng} / \mathrm{ml}$ & 98 & 3 & 4 & 29.4 & 39.2 \\
\hline $100 \mathrm{ng} / \mathrm{ml}$ & 93 & 0 & 1 & 0.0 & 9.3 \\
\hline
\end{tabular}

Note: ng/ml: nanogram per millilittre; percentages (\%): containing mean number of fungi at least one fungi; phagocytic index (PI): percentages containing at least one fungi $\mathrm{X}$ mean number of fungi per positive cell. A hundred cells macrophages againt 1000 cells Candida albicans per well. "total number of cell Candida albicans which is attached to the surface of the cell membrane of macrophages.

Table 2. Phagocytic index of macrophage phagocytozised activity toward Candida albicans after administration with many concentrations of GF 109203x in 30 minutes and 120 minutes. The higher level of GF $109203 x$ is given, the less PKCs are active, the less RMEs are formed, the less Candida albicans cells attached to the surface of macrophages ( $\%$ at least one fungi attached, collom 2 ).

\begin{tabular}{|c|c|c|c|c|c|}
\hline \multirow{3}{*}{$\begin{array}{c}\text { Concentration } \\
\text { of GF } \\
109203 x\end{array}$} & \multirow{3}{*}{$\%$} & \multicolumn{4}{|c|}{ phagocytic } \\
\hline & & \multicolumn{2}{|c|}{ per positive cell } & \multicolumn{2}{|c|}{ index } \\
\hline & & $30^{\prime}$ & $120^{\prime}$ & $30^{\prime}$ & 120’ \\
\hline $0 \mathrm{ng} / \mathrm{ml}$ & 92 & 1 & 10 & 9.2 & 92.0 \\
\hline $5 \mathrm{ng} / \mathrm{ml}$ & 90 & 0 & 10 & 0.0 & 90.0 \\
\hline $25 \mathrm{ng} / \mathrm{ml}$ & 92 & 0 & 6 & 0.0 & 55.2 \\
\hline 50 ng/ml & 80 & 0 & 4 & 0.0 & 32.0 \\
\hline $100 \mathrm{ng} / \mathrm{ml}$ & 60 & 0 & 1 & 0.0 & 6.0 \\
\hline
\end{tabular}

Note: ng/ml: nanogram per millilittre; percentages (\%) containing mean number of fungi at least one fungi; phagocytic index $(\mathrm{PI})=$ percentages containing at least one fungi $\mathrm{X}$ mean number of fungi per positive cell. A hundred cells macrophages againt 1000 cells $C$. albicans per well. In this moment the phagosomes was completed. "total number of cell Candida albicans which is attached to the surface of the cell membrane of macrophages.

mean the can part as the best courier or used in eicosanoids sintesis. Second, it more important, they can activate kinase serine/threonine protein kinase which selectively to phosphorelate in target cells. The effect of diacylglycerol can change with phorbol ester, that in plant production in the dependency with kinase C. The activity is direct. This reagents seen that this pathway always images the cellular response. More type cells can stimu- late the proliferation of cells culture if administrated with kinase $\mathrm{C}$ activator $[7,28]$.

Inhibitors of PKC could interact with the substratebinding site or with regulatory site of PKC. The structural similarity between bisindolylmaleimides, chelerythine and staurospoorine suggested that bisindolylmaleimides may be a competitive inhibitor with respect to ATP. The inhibition of PKC by bisindolylmaleimides was demonstrated to be highly dependent on the ATP concentration [4,29]. GF 109203X inhibited collagenand alpha-thrombin-induced platelet aggregation as well as collagen-triggered ATP secretion. However, ADPdependent reversible aggregation was not modified. In Swiss 3T3 fibroblasts, GF 109203X reversed the inhibition of epidermal growth factor binding induced by phorbol 12,13-dibutyrate and prevented [3H] thymidine incorporation into DNA, only when this was elicited by growth promoting agents which activate PKC [4].

Cell signalling includes: 1) Recognation of the stimulus by a specific receptor embedded wthin the membrane. 2) Transfer of a signal to its cytoplasmic surface. 3) Transmission of the signal to specific receptor molecules within the cytoplasm that trigger the cell's response 4) Cessation of the response as a result of the destruction or inactivation of the signaling molecule. Evidence from recent studies indicates are complex, for examples: 1) Signal from variety of unrelated growth factors, each binding to its own receptor, can convergence to activate a common effector. 2) Signal from same ligand, can diverge to activate a variety of different effectors, leading to cellular response. 3) Signal can be passed back and forth between different pathways, a phenomenon known as crosstalk $[3,30]$.

Some cells have a mechanism for internalism material needs from the environment outside the cell to inside the cytoplasmic through bubble dent derived from the plasma membrane. With the RME then macromolecules bind to specific RME projected on the outer surface of the plasma membrane [Stites and Terr, 1991]. Pinocytosis and macropinocytosis associated with the influx of fluids and soluble molecules into cells are characterized by increased metabolic activity of the cells. Phagocytosis process includes chemotaxis, catch-consuming macromolecules (by forming phagosome), digest (by forming secondary lysosomes and ongoing enzymatic degradation) and release it back that has been in the form of small particles particle non-antigenic [5,31].

PKC has the amino-therminal regulatory domain (20 $70 \mathrm{kDa}$ ) which is the binding site for phorbol ester. This domain is divided into carboxyl-terminal catalytic domain (approximately $45 \mathrm{kDa}$ ) consisting of a binder Adenosine Tri Phosphate (ATP) and substrate binding site where the two are connected by a flexible hinge region $[32,33]$. PKC conventional dependent calcium and 
DAG or phorbol ester as a cofactor, while PKC Novel depends only on DAG or phorbol ester. Atypical PKC is not dependent calcium nor DAG for maximal activity [3]. PKC can modulate for anti inflammatory [34-36], diabetes complication $[37,38]$, regulating of actin cytoskeleton [39], and apoptosis [40].

\section{Conclusion}

Research shows that activator PKC (PMA) can increase the expression of RME on macrophages. Another research shows that inhibitor PKC (bisindolylmaleimides) can decrease the expression of RME on macrophages.

\section{Acknowledgements}

We thank to Higher Education Competitive Research Project Ministry of Education and Culture Republic of Indonesia for Grand Featured Research Universities 2013, LPPT of Gajah Mada University and special thanks to acknowledge, Prof. Dr. Rafik Karsidi, MSc as a rector of Sebelas Maret University Surakarta Indonesia, Prof. Dr. Ir. Darsono, M. Si as a Chairman of the Institute for Research and Community Service, Prof. Dr. Zainal Arifin Adnan, SpPD-KR., FINASIM as a dean of Faculty of Medicine of Sebelas Maret University Surakarta Indonesia and special thanks to acknowledge Prof. Wihaskoro Sosroseno, DDS., Ph.D. for much inspirations to write this article.

\section{REFERENCES}

[1] P. E. Driedger and P. M. Blumberg, "Specific Binding of Phorbol Ester Tumor Promoters," Proceedings of the National Academy of Sciences of the United States of America, Vol. 77, No. 1, 1980, pp. 567-571. http://dx.doi.org/10.1073/pnas.77.1.567

[2] J. A. Swanson, "Phorbol Ester Stimulate Macropinocytosis and Solute Flow through Macrophages," Journal of Cell Science, Vol. 94, 1989, pp. 135-142.

[3] G. Karp, “Cell and Molecular Biology: Concepts and Experiments,” John Wiley \& Sons Inc., New York, 1996.

[4] D. Toullec, P. Pianetti, H. Coste, P. Belleverque, T. Grand-Perret, M. Ajakene, V. Baudet, P. Boissin, E. Boursier, F. Lariolle, L. Duhamel, T. Charon and J. Kirilovski, "The Bisindolylmaleimide GF 109203X Is a Potent and Selective Inhibitor of Protein Kinase C," The Journal of Biological Chemistry, Vol. 266, No. 24, 1991, pp. 15771-15781.

[5] D. Male, "Immunology and Illustrated Outline," 2nd Edition, Mosby, London, 1994.

[6] R. A. Bit, P. D. Davis, L. H. Elliott, W. Harris, C. H. Hill, E. Keech, H. Kumar, G. Lawton, A. Maw and J. S. Nixon, "Inhibitors of Protein Kinase C. 3. Potent and Highly Selective Bisindolylmaleimides by Conformational Restriction," Journal of Medicinal Chemistry, Vol. 36, No. 1, 1993, pp. 21-29. http://dx.doi.org/10.1021/jm00053a003
[7] S. Jaken, "Protein Kinase C Isoenzymes and Substrates," Current Opinion in Cell Biology, Vol. 8, No. 2, 1996, pp. 168-173. http://dx.doi.org/10.1016/S0955-0674(96)80062-7

[8] H. Fukasawa, M. Yamaguchi, Y. Hashimoto, Y. Endo, K. Shudo, "Enhancing Effect of Tumor Promoters, Phorbol Esters and Teleocidins on Nuclear Receptor-Mediated Transcription,” Biological and Pharmatical Bulletin, Vol. 23, No. 12, 2000, pp. 1414-1417. http://dx.doi.org/10.1248/bpb.23.1414

[9] D. Mochly-Rosen, K. Das and K. V. Grimes, "Protein Kinase C, an Elusive Therapeutic Target?” Nature Review Drug Discovery, Vol. 11, No. 12. 2012, pp. 937-957. http://dx.doi.org/10.1038/nrd3871

[10] S. X. Atwood, M. Li, A. Lee, J. Y. Tang and A. E. Oro, "GLI Activation by Atypical Protein Kinase C $\imath / \lambda$ Regulates the Growth of Basal Cell Carcinomas," Nature, Vol. 494, No. 7438, 2013, pp. 484-488. http://dx.doi.org/10.1038/nature11889

[11] G. T. Strickland, "Hunter's Tropical Medicine," 7th Edition, W. B. Saunders Company, Philadelphia, 1991.

[12] F. S. Rosen, L. A. Steiner and E. R. Unanue, "Macmillan Dictionary of Immunology,” Macmillan Reference Books, London and Basingstoke, 1989.

[13] D. P. Stites and A. I. Terr, "Basic Human Immunology," 1st Edition, Prentice-Hall International Inc., Upper Saddle River, 1991, pp. 34-44.

[14] I. Roitts, J. Brostoff and D. Male, “Immunology,” 3rd Edition, Mosby, St. Louis, 1993, pp.1-22.

[15] C. R. Young and C. J. Welsh, "Stress, Health, and Disease,” Cell Science, Vol. 2, No. 2, 2005, pp. 132-158.

[16] E. H. Vogel, M. E. Castro, P. A. Solar and F. A. Soto, "Enhancement of Pavlovian Conditioned Immunosuppression in Rats," Acta Neurobiologie Experimentalis, Vol. 67, No. 1, 2007, pp. 71-81.

[17] W. A. Dunn and A. L. Hubbard, "Receptor-Mediated Endocytosis of Epidermal Growth Factor by Hepatocytes in the Perfused Rat Liver: Ligand and Receptor Dynamics," The Journal of Cell Biology, Vol. 98, No. 6, 1984, pp. 2148-2159. http://dx.doi.org/10.1083/jcb.98.6.2148

[18] J. Feger, S. Gil-Falgon and C. Lamaze, "Cell Receptors: Definition, Mechanisms and Regulation of Receptor-Mediated Endocytosis," Celluler and Molecular Biology, Vol. 40, No. 8, 1994, pp. 1039-1061.

[19] H. S. Thatte and S. L. Schrier, "Comparison of Transferrin Receptor-Mediated Endocytosis and Drug-Induced Endocytosis in Human Neonatal and Adult RBCs,” Blood, Vol. 72, No. 5, 1988, pp. 1693-1700.

[20] A. Dautry-Varsat, "Receptor-Mediated Endocytosis: the Intracellular Journey of Transferrin and Its Receptor," Biochimie, Vol. 68, No. 3, 1986, pp. 375-381. http://dx.doi.org/10.1016/S0300-9084(86)80004-9

[21] A. A. Khine and C. A. Lingwood, "Capping and Receptor-Mediated Endocytosis of Cell-Bound Verotoxin (ShigaLike Toxin). 1: Chemical Identification of an Amino Acid in the B Subunit Necessary for Efficient Receptor Glycolipid Binding and Cellular Internalization," Journal of Cellular Biology, Vol. 161, No. 2, 1994, pp. 319-332.

[22] J. Mulholland, J. Konopka, B. Singer-Kruger, M. Zerial 
and D. Botstein, "Visualization of Receptor-Mediated Endocytosis in Yeast," Molecular Biology of the Cell, Vol. 10, No. 3, 1999, pp. 799-817. http://dx.doi.org/10.1091/mbc.10.3.799

[23] J. E. Coligan, A. M. Kruisbeek, D. A. Marquilies, E. M. Shevach, W. Strober and R. Coico, "Current Protocols in Immunology,” John Wiley \& Sons. Inc., New York, 1994.

[24] A. A. F. Machmoud, "Mononuclear Phagosytes and Resistance,” In: S. Kenneth and M. D. Warren, Eds., Immunology and Molecular Biology of Parasitic Infection, Black Well Scientific Publication, Boston, 1993. pp. 23-24.

[25] A. Prayitno and J. B. Suparyatmo, "Changes of BALB/C Mice Macrophages Mobility after Protein Kinase C Inhibitor Administration," Indonesian Journal of Clinical Pathology, Vol. 8, No. 1, 2000, pp. 18-22.

[26] E. C. Larsen, T. Ueyama, P. M. Brannock, Y. Shirai, N. Saito, C. Larsson, D. Loegering, P. B. Weber and M. R. Lennattz, "A Role for PKC- $\varepsilon$ in Fc $\gamma$ R-Mediated Phagocytosis by RAW 264.7 Cells,” The Journal of Cell Biology, Vol. 159, No. 6, 2002, pp. 939-944. http://dx.doi.org/10.1083/jcb.200205140

[27] S. J. Slater, M. B. Kelly, F. Taddeo, E. Rubin and C. D. Stubbs, "Evidence for Discrete Diacylglycerol and Phorbol Ester Activator Sites on Protein Kinase C. Differences in Effects of 1-Alkanol Inhibition, Activation by Phosphatidylethanolamine and Calcium Chelation," The Journal of Biological Chemistry, Vol. 269, No. 25, 1994, pp. 17160-17165.

[28] Y. P. Hwang, H. J. Yun, J. H. Choi, K. W. Kang and H. G. Jeong, "Suppression of Phorbol-12-myristate-13-acetateinduced Tumor Cell Invasion by Bergamottin via the Inhibition of Protein Kinase Cdelta/p38 Mitogen-Activated Protein Kinase and JNK/Nuclear Factor-KappaB-Dependent Matrix Metalloproteinase-9 Expression,” Molecular Nutrition and Food Research, Vol. 54, No. 7, 2010, pp. 977-990. http://dx.doi.org/10.1002/mnfr.200900283

[29] G. Harmati, F. Papp, N. Szentandrassy, L. Barandi, F. Ruzsnavszky, B. Horvath, T. Banyasz, J. Magyar, G. Panyi, Z. Krasznai and P. P. Nanasi, "Effects of the PKC Inhibitors Chelerythrine and Bisindolylmaleimide I (GF 109203X) on Delayed Rectifier $\mathrm{K}^{+}$Currents," MaunynSchmiedebergs Archives of Pharmacology, Vol. 383, No. 2, 2011, pp. 141-148. http://dx.doi.org/10.1007/s00210-010-0584-8

[30] C. Rosse, M. Linch, S. Kermorgant, A. J. Cameron, K. Boeckeler and P. J. Parker "PKC and the Control of Localized Signal Dynamics,” Nature Reviews Molecular
Cell Biology, Vol. 11, No. 2, 2010, pp. 103-112. http://dx.doi.org/10.1038/nrm2847

[31] J. W. William, B. Ernest, J. E. Allan and R. R. Wayne, "Hematology," 2nd Edition, Mc Grow Hill Book Company, A Blakistone Publication, New York, 1977.

[32] M. Thenawijaya, “Dasar-Dasar Biokimia,” Penerbit Erlangga, Jakarta, 1994.

[33] A. C. Newton, "Regulation of Protein Kinase C," Current Opinion in Cell Biology, Vol. 9, No. 2, 1997, pp. 161-167. http://dx.doi.org/10.1016/S0955-0674(97)80058-0

[34] S. Kuchera, H. Barth, P. Jacobson, A. Metz, C. Schaechtele and D. Schrier, "Anti-Inflammatory Properties of the Protein Kinase C Inhibitor, 3-[1-[3-(Dimethylamino)propyl]-1H-indol-3-yl]-4-(1H-indol-3-yl)-1H-pyrrole-2,5dione Monohydrochloride (GF109203X) in the PMAMouse Ear Edema Model,” Agents Actions, Vol. 39, No. 1, 1993, pp. C169-C173. http://dx.doi.org/10.1007/BF01972756

[35] T. Leppanen, "Protein Kinase $\mathrm{C}$ in the Regulation of Inflammatory Genes iNOS and TTP," Academic Dissertation, Medical School of the University of Tampere, Medisiinarinkatu 3, Tampere, 2010.

[36] S. Chand, N. Mehta, M. S. Bahia, A. Dixit and O. Silakari, "Protein Kinase C-Theta Inhibitors: A Novel Therapy for Inflammatory Disorders," Current Pharmaceutical Design, Vol. 18, No. 30, 2012, pp. 4725-4746. http://dx.doi.org/10.2174/138161212802651625

[37] P. Geraldes and G. L. King, “Activation of Protein Kinase C Isoforms and Its Impact on Diabetic Complications," Circulation Research, Vol. 106, No. 8, 2010. pp. 13191331. http://dx.doi.org/10.1161/CIRCRESAHA.110.217117

[38] A. Gonelli, C. Mischiati, R. Guerrini, R. Voltan, S. Salvadori and G. Zauli, "Perspectives of Protein Kinase C (PKC) Inhibitors as Anti-Cancer Agents,” Mini Reviews in Medical Chemistry, Vol. 9, No .4, 2009, pp. 498-509. http://dx.doi.org/10.2174/138955709787847967

[39] C. Larsson, "Protein Kinase C and the Regulation of the Actin Cytoskeleton," Cellular Signalling, Vol. 18, No. 3, 2006, pp. 276-284. http://dx.doi.org/10.1016/j.cellsig.2005.07.010

[40] A. M. Gonzales-Guerrico, J. Meshki, L. Xiao, F. Benavides, C. J. Conti and M. G. kazanietz, "Molecular Mechanisms of Protein Kinase C-Induced Apoptosis in Prostate Cancer Cells," Journal of Biochemistry and Molecular Biology, Vol. 38, No. 6, 2005, pp. 639-645. http://dx.doi.org/10.5483/BMBRep.2005.38.6.639 